\title{
Lexicon of Verbal Anger Expressions of Minangkabau Women
}

\author{
G Sastra $^{1}$, N Sabrian ${ }^{2}$ \\ \{1'gusdi@hum.unand.ac.id, 2nisasabrian8@gmail.com \} \\ ${ }^{1}$ Universitas Andalas Padang, Indonesia \\ ${ }^{2}$ Universitas Muhammad Yamin Solok, Indonesia
}

\begin{abstract}
Language in neurologic concept is the overall of someone's selfexpression when the person has to interact and communicate with others. due to that, language is not only limited to verbal, nonverbal, and the linguistic competence acquired by an individual, but it is also a reactive product from millions of nerve cells in the brain that are influenced by the culture where an individual is. Genetic heredity and how a person is treated, shapes an individual's personality in accordance to the sexes that have been created by the Almighty, that are men and women. Each will express oneself in the socio-cultural system. This paper discussed about how Minangkabau women express themselves through verbal expression that they use when they are angry. According to the brain's hemisphere's function, then a difference in how a person uses language is found, not only between the different sexes, but also caused by the cultural environment that shaped them. Also, the way Minangkabau women use language is influenced by the brain's hemisphere's function that shaped their personality. When Minangkabau women's emotional function worked well will their intelligence-vice versa, then the language used in an angry situation could mirror the character and sociocultural background that shaped them.
\end{abstract}

Keywords: Verbal Anger Expressions, Neurologic, Linguistic Competence, Hemisphere, Character

\section{INTRODUCTION}

The human beings use language to show verbal and non-verbal expressions. One of the main types of human emotions is anger (more dominant right hemisphere of the brain). It is actually a way of human to express their disapproval, rejection and uneasiness felt in the heart. Ones express their anger to keep the emotion in balance to calm the heart and mind. In fact, when the people get angry they will experience increasing blood pressure, rapid heart rhythm, and adrenaline rush. This extreme emotion reflects on their face, harsh verbal expression, strong gestures, and violent psychological responses.

The psychologists view anger as a primal and natural emotion essential for human survival or existence. However, the uncontrollable anger will hurt one's life including his or her social environment [1]. The neurologists believe anger is the result of uncontrollable function of right hemisphere of the brain and low emotional quotient. 
Moreover, the sociologists see it differently, to them anger is a human strategy to manipulate their social system. Women often show this emotion in the increasing pitch and tone in their utterance. Female Minangkabaunese is no exception. They grow in matriarchal tradition of Minangkabau culture [2], they express the anger in a way worthy of research.

The Minangkabau women is the guardian of Minangkabau blood line. Therefore, they are bound to the rule of keeping their utterance and behavior, and submit to the Minangkabau tradition based on adat (culture) and Islamic tenets (adat basyandi syarak) [3]. They have to be able to differentiate the good things from the bad ones, halal from haram, and other material aspects of behavior because they function as the keeper of Minangkabau blood line.

Therefore, they are responsible to educate the Minangkabaunese to have a good attitude and behavior, and high sense of morality. This responsibility is also required for the next generation. This socio-cultural role puts them on important status for social function [4], [5]. There is problem in Minangkabau society if a tribe does not have a female offspring. That tribe will be vanished [6]. There is no more bloodline to continue. Since Minangkabau has many tribes or suku and adopts matriarchal system, the role of a woman in a family or a tribe is beyond comparable. A Minangkabau woman in Minangkabau society is called padusi Minang.

Padusi Minang is highly respected in Minangkabau society and tradition, consequently they become the badge of honor of their tribe and family. Their behavior and attitude are viewed by the society as the level of honor of the family and the tribe, meaning, any bad behavior and attitude will hurt the honor of their tribe. Therefore, every member of the tribe and family will try to protect the honor of their female members [6].

The family will not tolerate any bad deed which hurts the honor of their female offspring. Padusi Minang share the ordeal, happiness, and respect with every member of their family and tribe. The family and tribe prevent any bad deed done by their female members. To the family and tribe, the honor of padusi Minang (the matriarch) is everything. They will protect them at all cost. Thus, the members of the tribe and family are responsible to protect the honor of their female members. This so-called honor relates to some of conducts. One of them is the way of speaking.

Based on the emotional quotient of right hemisphere of the brain, the anger is a natural process so violent and therefore it can hurt many social systems, tradition, religion, and culture. This mechanism is caused by a limbic system in human brain regulating the emotion. That system is called amygdala [7]. In essence, amygdala drives a motoric mechanism resulting the motion of the muscle to produce expression and bioacoustics of the voice and prosody different from normal emotion. The limbic system in a female brain is bigger than that of the male one. This is one the factors why women are more emotional than the men. Padusi Minang of course experience this neurological mechanism.

There is a fixed system of tradition and norm in Minangkabau society, but in fact there are Minangkabau women still use lexicons considered taboo to use in utterance:

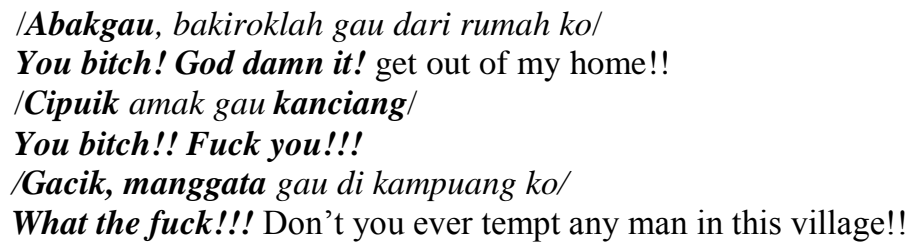

The lexicons in bold are the cursing words in Bahaso Minang considered taboo for daily communication. However, the Minangkabau women still use them in anger. The prosody and bioacoustics include pitch and tone undergo a rapid spike. The increasing prosody and tone 
make the anger more violent resulting harsh utterance. The missing of social and religious control will produce more anger lexicons.

The expression of amygdala and limbic system on right hemisphere will raise significantly. This research focuses on describing bioacoustics prosody of Minangkabau women's utterance in expressing their verbal anger. This study also classifies the anger lexicons expressed as verbal behavior. This research is significant to conduct because if the anger or taboo lexicons are used in three generations and the number of the user's increase, there will be a dire consequence showing the Minangkabau legacy of culture and its religious tradition broken in the inside. It includes the way of speaking and expressing verbal behavior.

Prins [7] states both hemispheres are different in anatomy. The left hemisphere shows more sensoric and motoric organs. Its primary region is wider. In right hemisphere, the wider region is the cortex of parietal association and prefrontal area. Goldberg and Costa [8] explain the left hemisphere is associated with the process of requiring singular fixation, whereas the right hemisphere functions for the processing of more complex tasks such as consciousness, and note and tone identification in music and human sound.

The diffused codification process of information also occurs in the right hemisphere. In the left hemisphere, more linear codification of vocal happens. Yuliani [9] states the left hemisphere is more analytical, more precise in calculation and seconds, time management, and is more focused on the sequence of orders, numbers and mathematical rules. Obler also describes the front end of parietal lobes on the right hemisphere deals with feeling and perception.

One of the organs inside the human body regulating the emotion of anger is definitely the brain. Someone experiences the anger is an actual process of limbic system. The limbic itself composed by some subcortical nucleus (thalamus, hypothalamus, septum, and amygdala), frontal insula, some medial structures on lobes (gyrussingulars), hippocampus, and other cortical area at the skirts [10].

The result of the research shows amygdala is the area regulating human emotion. The process of emotion in the brain drives the motoric system resulting the motion of the muscles. This mechanism produces expressions, gestures, facial expressions and prosody (voice tone).

Human brains share functions in general regardless sex and gender. However, there are some minor yet significant differences regarding the aspects of sex and gender, to be precise. Those differences lie in the function of right and left hemisphere [11]. Both hemispheres on female and male human brain show some different functions after puberty.

Such differences occur are caused by internal and external factors. Male and female human brains show minor different structures and size. Woman's brain has a bigger and a wider limbic system than that of man's [12]. This difference makes the woman more emotional and easier to express her emotion. Moreover, the external aspects are about the impact of socio-cultural environments to women's behavior development. The differences happen in the childhood (child rearing), and the influence of social aspects and education that construct the way of expressing emotion. These factors also have impact to the way of men and women expressing their emotion in language.

Ross and Thomson [13] states the man and woman are born to the world of fixed statuses and role. Therefore, they view the world differently depending on their sex and gender. They also communicate in different way because they acquire different style of communication during the childhood. Ratnasari and Suleeman [14] also state the child rearing process and the socialization have an impact to women behavior in expressing their emotion differently from the men.

This research focusses on the utterance of Minangkabau women 's anger expression because they have more freedom to express the emotion in language use. Their prosody of 
intonation is observed by means of bioacoustics. Praat uses speech analyzer to analyze the record of utterance. Prins [7] states the prosody also shows the difference in motoric controlling. Emotion or anger, naturally, will have some impacts in the prosody. Thus, the prosody shows the women 's feeling when they talk. The prosody expressing the speakers 'feeling or motion defines the prosody of emotion. The right hemisphere of the brain regulates this prosody through process in cortex, subcortex, and base ganglion.

The aspects of utterance, not only the prosody, also describe one's emotion or feeling. Harsh language such as curse and damnation often used in anger. However, there are some exceptions based on the traits of human behavior. More introverted person expresses the anger in tears, and more extroverted one will express it in harsh words. This cursing utterance found in numerous anger lexicons used by Minangkabau women. Some social factors are responsible for this phenomenon.

\section{RESEARCH METHOD}

This research uses longitudinal observation in four traditional market places in West Sumatra: Padang Tarok traditional market in Baso-Agam prefecture, Solok traditional market in Solok prefecture, Painan traditional market in Painan, and Padang traditional market in Pasar Raya Padang of Padang city. These locations represent both darek and rantau regions in West Sumatra. The data are taken from the Minangkabau women's utterance in anger and conflicts. The data are also taken from some houses where the conflicts occur and the anger lexicons are used.

The solicitation technique and repetitive comparison are used longitudinally in the location of observations. The data are recorded. The data are also taken from some schools in the villages. The anger lexicons from female students are observed and recorded. The age of Minangkabau women using anger lexicons are classified and validated. This research also uses informants to collect data on anger or taboo lexicons by means of solicitation.

\section{RESULTS AND DISCUSSION}

Kato [15] states the Minangkabau women are the guardian of the bloodline, so they have to be pure, and submit to the rule of Islamic sharia based Minangkabau rules and ethics (Adat basyandi Syarak). They have to act, see, and accept only good deeds. They also have to be proficient in understanding halal and haram since their major responsibility focuses on keeping the blood line and bear the next generation. The Minangkabau women are truly responsible in the education of ethics and norms for Minangkabau younger generation. If one family bears no female offspring, that family draws closer to perish because Minangkabau is a matriarchal society.

In Minangkabau society, the women are the badge of honor of the family. Their conduct determines the honor of the family. Therefore, every member of the family protects the honor of their female members. Padusi Minang is highly respected in Minangkabau society and tradition, consequently they become the symbol of honor of their tribe and family. Their behavior and attitude are viewed by the society as the level of honor of the family and the tribe, meaning, any bad behavior and attitude will hurt the honor of their tribe.

Therefore, every member of the tribe and family will try to protect the honor of their female members. The family will not tolerate any bad deed which hurts the honor of their female offspring. Padusi Minang share the ordeal, happiness, and respect with every member of their family and tribe. The family and tribe prevent any bad deed done by their female members. 
To the family and tribe, the honor of padusi Minang (the matriarch) is everything. They will protect them at all cost. Thus, the members of the tribe and family are responsible to protect the honor of their female members. This so-called honor relates to some of conducts. One of them is the way of speaking.

Since the Minangkabau women are the badge of honor of their family and tribe, they should be able to control their verbal expression even in anger. They should not let their extreme emotion best them in conflicts or violent dialogues. How about the fact in the field of observation? Does it tell another story? How do the Minangkabau women think of the cultural ethics and norms of politeness when they get angry in verbal conflicts?

It hard to find out the Minangkabau women in general using taboo and cursing utterances in their anger. The family or the tribe which is still keeping the Minangkabau code of conducts, norms and ethics will not show the cursing utterances and taboo lexicons from their female members even in anger. The female members will control their verbal expressions. However, the fact tells another tale in the places of social conflicts, traditional markets, and domestic violence.

They use taboo and cursing utterances composed of anger lexicons in those places. Their educational background seems to be responsible in this case. Most of Minangkabau women who use the taboo and anger lexicons in their verbal expressions have low education. They only finish junior high school, and their family educational background even do not finish the elementary school.

The result of data analysis shows the use of taboo and cursing words in anger utterances. The Minangkabau women are categorized at age and education. Check out the following table:

Table 1. The percentage of Minangkabau women using taboo lexicons in anger

\begin{tabular}{ccc}
\hline Age & Education & Percentage \\
\hline $12-14$ years & Elementary School & 18 \\
$15-25$ years & Junior High School & 35 \\
$26-44$ years & Junior High School & 24 \\
45 years and higher & Elementary Shool & 23 \\
\hline
\end{tabular}

The use of anger and taboo lexicons in cursed utterances is determined by age and educational background. The age rate of the users shows the puberty and maturity age, meaning, 12 years old up to 45 years old. It is obvious that the age is one of the causal factors for the users in expressing the emotion. The age of adolescent (15-25 years old) shows high percentage at 35 percent. The lowest percentage found at the age 12-14 years old because they barely know those words and strict social control in social environment.

The growth of right hemisphere in literacies occurs before the puberty. Minangkabau women at 45 years old also show lower percentage because the decreasing function of the brain and the increasing amount of oxytocin agent in the brain. This chemical agent has specific effects to human social behavior.

The aspects of education also function as the causal factors. The use of taboo and cursing lexicons in expressing the anger shows higher percentage on lower education women: elementary and junior high school. The Minangkabau women on higher degree of education such as senior high school and university, show almost none of using those taboo and cursing lexicons. This finding still requires a deeper study regarding the effects of education to human brain hemisphere growth and development during adolescent and maturity. The percentage of using those taboo and cursing words on higher education women is just about zero. 
If higher percentage found, that case is categorized as case study on thinking and language disorder. The worst case can be a mild schizophrenia. The psychiatrist and psychologist treatments are needed for this type of case. Another case, if these taboos and cursing words used by Minangkabau men, it shows the psychological, neurological, and social disorder. The types of anger and taboo lexicons used by Minangkabau women are as follow:

Table 2. the categories of anger utterance and lexicons of Minangkabau women

\begin{tabular}{|c|c|c|c|}
\hline $\begin{array}{l}\text { The type of anger } \\
\text { utterance }\end{array}$ & Anger and cursing lexicons & Utterances & Speakers \\
\hline Address terms & $\begin{array}{l}\text { Amak (kau), kau, mandeh, } \\
\text { ang, poyok, lonte, apak (kau), } \\
\text { ayah (kau), urang, gacik, } \\
\text { pantek, paja, piak, anak } \\
(\text { kau }), \text { aden, den }\end{array}$ & $\begin{array}{l}\text { Amak kau, } \\
\text { bakiroklah kau poyok, } \\
\text { den rameh muncuang } \\
\text { kau tu anjiang }\end{array}$ & All ages \\
\hline Lexicons on human & $\begin{array}{l}\text { Female genital, male genital, } \\
\text { parents, other human organs. }\end{array}$ & $\begin{array}{l}\text { Pantek, lancik, godok, } \\
\text { kaduik, kalempong, } \\
\text { muncuang, cipuik, } \\
\text { arang }\end{array}$ & 27 years old \\
\hline $\begin{array}{l}\text { Lexicons on } \\
\text { animals }\end{array}$ & $\begin{array}{l}\text { Anjiang, baruak, kuciang, } \\
\text { ulek, lado, miang, } \\
\text { kapindiang, kapunduang, } \\
\text { kapuyuak, gacik, antubalawu, } \\
\text { dubilih, cipuik }\end{array}$ & $\begin{array}{l}\text { Jan baciracau jo kau } \\
\text { lai anjiang, kapuyuak } \\
\text { pajatu mah, }\end{array}$ & $\begin{array}{l}15- \\
27 \text { years old }\end{array}$ \\
\hline other taboo lexicons & $\begin{array}{l}\text { Galenjek, mantiak, bandang, } \\
\text { maangok, bakirok,pantak, } \\
\text { garua, ongeh, lato, barangin, } \\
\text { andia, busuak, ariang, } \\
\text { matikarancak-an, jinjiang, } \\
\text { engak, mangangkang, jangak, } \\
\text { kalera, jongkek }\end{array}$ & $\begin{array}{l}\text { All utterances use kau } \\
\text { and gau }\end{array}$ & All ages \\
\hline
\end{tabular}

Most of anger and cursing lexicons used by Minangkabau women are taboo. Those words are forbidden to use in normal social interactions, dialogues, and events on Minangkabau cultures. The use of these taboo lexicons is found in social and daily life of Minangkabau women, but its use is limited. Ethics in using those taboo words are not to be taken so lightly. There other aspects limiting the use, such as: the mind, feeling, socio-cultural factors and the attitude of the users.

The use of taboo lexicons when a woman expressing her anger includes the address terms on human genitals, animals, and other taboo lexicons in Minangkabau culture. Those taboo lexicons are used offensively. The Minangkabau women used these taboo and offensive address terms to express or channel their anger when the adrenaline kicking. Other aspects also show the impacts to this verbal behavior such as low education background, the lack of family and social control, and low spirituality.

The dictions and taboo lexicons used by these Minangkabau women occur at all ages up to below 45 years old. All those taboo dictions are found in the mainland of Minangkabau (darek) and coastal areas (pesisir/rantau). However, there are some homonyms found in both areas such as cipuik refers to snail in the mainland (darek). It is not offensive and not taboo either. However, 
the term cipuik in coastal region equals to female genital. It is taboo and offensive to use in the utterance.

The address terms kau and gau are used to express the anger in both offensive and nonoffensive utterances. For example: "barangkeklah kau/gau dari rumah den ko" (get out of my house!!!). This is not offensive but still shows the anger. The following example is offensive: "bakiroklah kau/gau dari rumah den!!" (Get out of my house!!). Moreover, the address term den/aden is always used by the Minangkabau women in the mainland and coastal region to express their anger. The exception occurs in Bukittinggi. This term is not always used for some reason.

The term den/aden in Bukittinggi equals to the term ambo referring to first person singular address term. The term awak also has the same meaning but politeness wise, it refers to more neutral use. The example: Kan lah den kecek-an ka gau(I have told you). In Bukittinggi, this utterance is not offensive and does not express the anger either, but in other areas it refers to expressing the speaker's anger.

However, if the speakers use the taboo address terms and lexicons, the meaning equals to anger in all locations. No exception. The users or the speakers will be considered ignorant to Minangkabau traditions and ethics. They are regarded unrefined and uneducated people. Even more than that, they will be considered people without mother. This is extremely offensive. The Minangkabau women who use these words are considered not Minangkabau women since the women of Minangkabau has virtues and noble use of language. A true Minangkabau woman will calm the heart of the people.

How the Minangkabau women express their anger is actually affected by the treatment to their brain hemispheres in the childhood 0-12 years old. In the years of growing up, the girls will record all verbal behavior from their environment and family. Their brains process this information and save it as data unconsciously. If there is a stimulus, they will respond and produce the lexicons.

The women will use those lexicons if being permitted by their social environment. The society decides which lexicons are allowed to use and which ones are not. All offensive and cursing lexicons used by Minangkabau women for expressing or channeling their anger are not allowed to use verbally in social interaction.

However, those lexicons do exist and function as the words in Bahaso Minangkabau (Minangkabaunese language). The society will decide the use of those lexicons to express the anger, either allowed or prohibited. To sum up, the social environment shows a significant impact to Minangkabau women's verbal behavior in expressing their anger.

\section{CONCLUSIONS}

Woman has a bigger and wider limbic system than that of the man. Therefore, woman shows a different way to express their feeling and emotion from the man. The woman is more emotional and is easier to express their feeling than the man does. Since the Minangkabau women are the badge of honor in their family, consequently they have to show more self-control in the use of language for expressing anger, meaning, they do not have to use offensive taboo words and cursing lexicons to other speakers.

A family embracing the Minangkabau tradition, ethics, and norm barely show a Minangkabau woman express their anger in offensive and unrefined manner. The Minangkabau women use offensive and cursing utterances in social conflicts, traditional markets, and abusive family. 
The use of taboo and cursing lexicons in the utterance of Minangkabau women is caused by two factors: 1) age, 2) education. Mostly the users of taboo and cursing words are at the age of puberty and below 45 years old. This phenomenon occurs because of the effects of age to human brain right hemisphere in regulating the emotion or the feeling. The age of adolescent $(15-25$ years old) shows higher rate at 35 percent. The Minangkabau women at the age of 12-14 years old show the lowest rate of using taboo and cursing utterances.

The way of Minangkabau women expressing their anger is also caused by the treatment to the right hemisphere function of the brain during their childhood (o-12 years old) as the time of character and behavior building.

\section{REFERENCES}

[1] Stepan and Harris, "Anger in social inveromntal," Journal Humanities, pp. 215-240, 2011.

[2] M. Mawangir, "Modernization Of Islamic \&quot;Surau\&quot;; Traditional Education In West Sumatera, Indonesia,” Journal of Islamic Studies, vol. 3, no. 2, pp. 2333-5912, 2015.

[3] T. Kato, "Change and Continuity in The Minangkabau Matrilineal system," Indonesia, vol. 25, no. April, pp. 1-16, 2008.

[4] Y. P. W. Suseno, "PENGGAMBARAN IDENTITAS ETNIS MINANG DALAM FILM TABULA RASA,” Universitas Airlangga, 2016.

[5] I. Iskandar, "Perempuan dan Mitos Demokrasi Minang," Analisis Sejarah, vol. 5, no. 1, pp. 35-46, 2014.

[6] R. S. Kipp and P. R. Sanday, "Women at the Center: Life in a Modern Matriarchy," Contemporary Sociology, vol. 32, no. 5, p. 562, Sep. 2003.

[7] Pins, Gangguan Komunikasi Fungsi Hemisfer Kanan dan Pembagian Tugas Hemisfer. Jakarta: Djambatan, 2000.

[8] Goldberg and Costa, "Left brain and Right brain function," 2018. [Online]. Available: cognitivepsychology/a/Aleft-brain-right-brain. [Accessed: 20-Aug-2004].

[9] Yuliani, "Perbedaan Gender dalam Penguasaan Bahasa Dipandang dari Perspektif Psikologi Pendidikan," Jurnal Ilmiah Ilmu Pendidikan, vol. XIII, no. 1, 2013.

[10] W. Tango, "Man and Women Brain," Neurolinguitic Journal, no. 54, pp. 167-175, 2006.

[11] G. Sastra, "Bahasa Perempuan Berdasarkan Hemisfer Otak," 2017.

[12] Gurian, "TindakTutur Bahasa Perempuan," Majalah Bahasa, pp. 70-75, 2014.

[13] E. . Ross and R. D. Thomson, "Lateralisation of Affective Prosody in Brain and the Callosal Integration of Hemishperic Language Function," Brain and Language, vol. 56, pp. 27-54, 1997.

[14] Ratnasari and Suleeman, "Women Behavior and Emotion Different with Man," Journal of Behavior, pp. 35-52, 2015.

[15] T. Kato, Matriliny and Migration: Evoving Minangkabau Tradition in Indonesia. Ithaca \& London: Cornell University Press, 2013. 
